\title{
体動計による早産児の多動性・睡眠障害の評価と 母親のメンタルヘルス支援
}

\section{中川真智子}

聖路加国際病院小览科

(ストレス科学研究 2015, 30, 184-185)

\section{目的}

本研究の目的は，1）ADHDハイリスク群の早産児 （出生体重 $1500 \mathrm{~g}$ 未満の早産児）の多動性・睡眠障害 を体動計で客観的に評価する方法を考案する，2）早 産児の活動・睡眠障害と母親のメンタルヘルスの関連 を明らかにし, 1 歳半健診以降の療育指導・母親への 子育て支援を促進することである。

\section{方 法}

\section{【研究 1 : 早産児の多動性・睡眠障害の評価】}

早産・正期産で出生した 1 歳半の幼児を対象に, 体 動計システムを用いて児の活動・睡眠を評価する。こ の研究により, 作業仮説「1 歳半において早産児では, 正期産児に比べ, 多動性が認められ, 睡眠障害の発症 率が高い」を検証する。

1. 対象 :

1 歳半の幼児（合計 34 名）を以下の 2 群に分け体 動計を用いて児の活動・睡眠を評価する。

1）正期産（出生体重 $2500 \mathrm{~g}$ 以上）で出生した 1 歳 半の健康な幼児 : 19 名

2) 出生体重 $1500 \mathrm{~g}$ 未満で早産した 1 歳半相当の幼 児：15 名

2. 評価項目・解析方法 :

本研究の主要評価項目を, (1)夜間睡眠効率, とし出 生体重の影響を評価する。また, 副次評価項目を, (2) 昼間の活動量 (=多動性指標), (3)心理発達検査指数 (新 版 K 式）とし，評価する。具体的には，24 時間の活 動パターンを体動計システムで評価する。また, 1 歳 半 (早産児では 1 歳半相当) での体重・身長・頭囲測 定, 心理発達検査を行う。統計解析は各評価項目につ いて $\mathrm{t}$ 検定を行う。

\section{【研究 $2 ： 母$ 親のメンタルヘルスの評価】}

研究 1 で調查協力に同意を得た対象児の母親を対象 に，母親のメンタルヘルスを評価する。

1. 対象 :

出生体重 $1500 \mathrm{~g}$ 未満で早産した 1 歳半相当の幼児 の母親：15 名

2. 評価項目・解析方法 :

メンタルヘルスを, 乳幼児睡眠調査票による母親の 児の睡眠に対する不安判定，および抑うつ状態および 育児ストレスのスコアとし，評価する。メンタルヘル スは, エジンバラ出産後うつ病評価尺度 (EPDS), 日本 版 PSI-SF 実用版 (Parenting Stress Index-Short form, 平松ら，2006）を用いて評価する。統計解析は各評価 項目について $\mathrm{t}$ 検定を行う。

\section{結果・考察}

\section{1. 内容}

本研究では, グループ 1 の正期産児は聖路加国際病 院で出生した児を対象とし, 聖路加国際病院小児医療 センターウェルベビークリニック（乳幼巟健診外来） を 1 歳または 1 歳半健診で受診した際に研究参加を依 頼し了承を得た。グループ 2 の出生体重 $1500 \mathrm{~g}$ 未満 で早産出生した修正 1 歳半の児は, 聖路加国際病院で 出生し新生児集中治療室に入院, 退院後も同院発達支 援外来（フォローアップ外来）を受診している児に研 究参加を依頼し了承を得た。

\section{2. 実施経過}

(1) 経過概要

各児は 7 日間アクチグラフを装着した。この間の睡 眠記録（睡眠表）を保護者に依頼した。アクチグラフ の計測結果と睡眠表をもとに解析を国立精神・神経医 療研究センターにて行った。母へのメンタルヘルス評 価も同時に行った。 
Table 1 出生情報

\begin{tabular}{llcc}
\hline & & 正期産児 & 早産児 \\
\hline 性別 & 男 (人) & 12 & 11 \\
& 女 (人) & 7 & 4 \\
出生時 & 中央值 (標準偏差) & $34.6(3.8)$ & $37.5(5.7)$ \\
母年齢 (歳) & 範囲 & $26.0-41.0$ & $27.0-48.0$ \\
出生順 & 第 1 子 (人) & 12 & 10 \\
& 第 2 子以降 (人) & 7 & 5 \\
出生週数（週） & 中央值（標準偏差） & $39.9(1.1)$ & $29.5(1.9)$ \\
& 範囲 & $37.6-41.9$ & $26.6-34.0$ \\
アクチグラフ & 中央值（標準偏差） & $19.4(1.3)$ & $19.4(0.9)$ \\
計測時月齢(月) & 範囲 & $17.8-22.3$ & $18.1-21.3$ \\
\hline
\end{tabular}

Table 2 身体情報

\begin{tabular}{|c|c|c|c|}
\hline & & 正期産児 & 早産児 \\
\hline \multicolumn{4}{|c|}{ 出生時身体計測値 } \\
\hline 体重 (g) & $\begin{array}{l}\text { 中央値（標準偏差） } \\
\text { 範囲 }\end{array}$ & $\begin{array}{c}3150.4(273.2) \\
2668.0-3844.0\end{array}$ & $\begin{array}{c}1109.2(244.7) \\
592.0-1438.0\end{array}$ \\
\hline 身長 $(\mathrm{cm})$ & $\begin{array}{l}\text { 中央値（標準偏差） } \\
\text { 範囲 }\end{array}$ & $\begin{array}{l}49.7(1.4) \\
47.0-53.5\end{array}$ & $\begin{array}{l}36.9(3.2) \\
28.0-41.0\end{array}$ \\
\hline 頭囲 (cm) & $\begin{array}{l}\text { 中央値（標準偏差） } \\
\text { 範囲 }\end{array}$ & $\begin{array}{l}33.6(1.6) \\
30.5-36.0\end{array}$ & $\begin{array}{l}26.5(1.6) \\
25.0-29.0\end{array}$ \\
\hline \multicolumn{4}{|c|}{ アクチグラフ計測時の身体計測值 } \\
\hline 体重 (kg) & $\begin{array}{l}\text { 中央値（標準偏差） } \\
\text { 範囲 }\end{array}$ & $\begin{array}{c}10.5(0.9) \\
9.2-12.3\end{array}$ & $\begin{array}{l}9.6(0.9) \\
7.8-11.4\end{array}$ \\
\hline 身長 $(\mathrm{cm})$ & $\begin{array}{l}\text { 中央値（標準偏差） } \\
\text { 範囲 }\end{array}$ & $\begin{array}{l}80.2(2.7) \\
73.0-83.9\end{array}$ & $\begin{array}{l}79.7(2.3) \\
75.5-83.4\end{array}$ \\
\hline 頭囲 $(\mathrm{cm})$ & $\begin{array}{l}\text { 中央値（標準偏差） } \\
\text { 範囲 }\end{array}$ & $\begin{array}{l}47.8(1.1) \\
45.6-49.7\end{array}$ & $\begin{array}{l}47.6(1.7) \\
44.8-50.5\end{array}$ \\
\hline
\end{tabular}

(2) 結果

本年度の症例数は, 正期産児 19 名, 早産児 15 名で あった。母へのメンタルヘルス評価症例は15名であっ た。

（1) 対象児のプロファイル：出生情報（Table 1), 身体情報（Table 2）を示す。

(2) 体動計（アクチグラフ）計測結果

i ) 昼間の活動量

早産児では正期産児に比べ，昼間の活動量が少な かった (早産児 221.9 回 / 分 \pm 24.6 , 正期産児 232.7 回 / 分 $\pm 16.7, \mathrm{t}$ 検定, $\mathrm{p}<0.01)$ 。

ii ) 睡眠指標

早産児では正期産児に比べ, 入床から起床までの時 間が短かった（入床〜起床 : 早産児 9.9 時間 \pm 1.1 , 正 期産児 10.1 時間 $\pm 0.9, \mathrm{t}$ 検定, $\mathrm{p}<0.05)$ 。また, 睡眠 効率には差がなかった（早産児 $87.4 \% \pm 8.8$, 正期産児 $88.7 \% \pm 10.0, \mathrm{t}$ 検定, $\mathrm{p}>0.05)$ 。

iii) 心理発達検査指数

早産児を対象に行った心理発達検査（新版 K 式）指 数は全領域DQ91.2 \pm 13.5 , 姿勢運動領域 $88.6 \pm 13.8$, 認 知適応領域 $92.1 \pm 13.5$, 言語社会 $87.8 \pm 18.2$ であった。

(3) 母のメンタルヘルス評価

早産児の母 15 名のうち, 児の睡眠に心配を抱いて いた母は 9 名であった。

\section{3. 考察}

（1）早産児の多動性

本研究の途中経過より, 修正 1 歳半では早産児の運 動発達の未熟性により副次評価項目：多動性を評価で きない可能性が示唆された。

極低出生体重児と超低出生体重児の 2 群の検討：

この途中結果を, 予定症例数 (25 名) に到達した時 点で再評価する。合わせて, 極低出生体重児と超低出 生体重児の 2 群間に差がでないかどうかを確認する。

（2）早産児の睡眠障害

本研究の途中経過より, 修正 1 歳半では, 主要評価 項目：睡眠効率に差を認めなかった。一方, 睡眠時間 の短縮傾向が早産児の特徵として抽出された。

早産児における睡眠時間の短縮と発達障害の相関関係:

この途中結果を, 予定症例数 (25 名) に到達した 時点で再評価する。合わせて, 睡眠時間の短縮を認め る早産児と短縮を認めない早産児の 2 群を比較し, 新 版 $\mathrm{K}$ 式発達検査スコアに差がないかどうか検討する ことにより, 修正 1 歳半における睡眠時間短縮等の睡 眠障害と早産児の発達遅滞に相関関係が存在しないか どうか, を確認する。

（3）母親のメンタルヘルス

本研究の途中経過より, 修正 1 歳半では早産児の母 親の半数以上が児の睡眠に対して心配を抱いており, 母親の育児ストレスが高い可能性が示唆された。評価 スコアの解析をすすめているところである。さらに, 予定症例数に到達した時点で再評価する。

\section{得られた結果の社会貢献性・新規性・独創性}

\section{社会的意義・独創性}

1. ADHDリスク群の早産児に対するスムーズな早 期介入の実現

早産児では, 3 つ評価項目（多動性, 夜間睡眠時間, 発達検査指数) について, (1)正期産児と有意差がない 健常群と(2)有意差があるADHDリスク群の2つのサブ グループに分類され, 早産児におけるADHDリスク群 の特徵が明らかになる。この結果にもとづき, ADHD リスクをもつ早産児に対して，3歳時における専門医 による確定診断前に, 1 ～ 3 歳における適切な夕イミ ングで早期療育開始へのアプローチが可能となる。

2. ADHD リスク群早産児を保育する養育者に対す る子育て支援

早産児の多動性・睡眠障害の評価と母親のメンタル ヘルスを同時に評価することで, ADHDリスク群を 養育する母親のメンタルヘルスの悪化を客観的に捉え ることができると期待される。その結果, 母親の育児 ストレスを軽減するとともに, ADHDリスク群の早 産児に対するより専門的な育児支援が可能となる。 